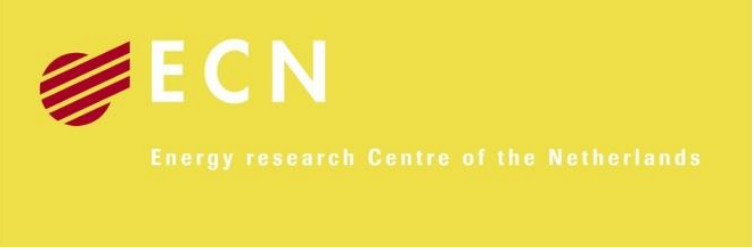

\title{
Leaching characterisation and geochemical modelling of minor and trace elements released from recycled concrete aggregates
}

\author{
C.J. Engelsen \\ H.A. van der Sloot \\ G. Wibetoe \\ H. Justnes \\ W. Lund \\ E. Stoltenberg-Hansson
}

Published in Cement and Concrete Research 40 (2010) 1639-1649 


\title{
Leaching characterisation and geochemical modelling of minor and trace elements released from recycled concrete aggregates
}

\author{
Christian J. Engelsen ${ }^{\mathrm{a}, *}$, Hans A. van der Sloot ${ }^{\mathrm{b}}$, Grethe Wibetoe ${ }^{\mathrm{c}}$, Harald Justnes ${ }^{\mathrm{a}}$, \\ Walter Lund ${ }^{\mathrm{c}}$, Erik Stoltenberg-Hansson ${ }^{\mathrm{d}}$ \\ a SINTEF Building and Infrastructure, P.O. Box 124 Blindern, N-0314 Oslo, Norway \\ ${ }^{b}$ Energy Research Centre of The Netherlands, The Netherlands \\ c Department of Chemistry, University of Oslo, Norway \\ d Norcem AS, Norway
}

\section{A R T I C L E I N F O}

\section{Article history:}

Received 8 February 2010

Accepted 2 August 2010

\section{Keywords:}

Crushed concrete

Metals

Leaching

Equilibrium

Geochemical modelling

\begin{abstract}
A B S T R A C T
The $\mathrm{pH}$ dependent release of $\mathrm{Cd}, \mathrm{Cr}, \mathrm{Cu}, \mathrm{Mn}, \mathrm{Mo}, \mathrm{Ni}, \mathrm{Pb}, \mathrm{V}$ and $\mathrm{Zn}$ from different recycled concrete aggregate samples was determined. Geochemical speciation modelling was applied on the concentrations of $\mathrm{Cu}, \mathrm{Cr}$, Mo and $\mathrm{Ni}$ in the leachates in order to predict the measured concentrations and the specific release mechanisms. The model was able to reproduce the characteristic $\mathrm{pH}$ dependent release patterns for these elements and reasonable to sometimes excellent matches between the predicted and measured concentrations were achieved. Binding of $\mathrm{Mo}$ and $\mathrm{Cr}$ as oxyanions $\left(\mathrm{MoO}_{4}{ }^{2-}\right.$ and $\mathrm{CrO}_{4}{ }^{2-}$ ) to ettringite was modelled with fair agreement for $\mathrm{Cr}$ only. For $\mathrm{Cu}$ and $\mathrm{Ni}$, the predicted and measured concentrations agreed well for the partly carbonated sample at high alkaline $\mathrm{pH}$ (11-13). The importance of complexation to humic substances was also shown in samples derived from construction debris.
\end{abstract}

(C) 2010 Elsevier Ltd. All rights reserved.

\section{Introduction}

Leaching characterisation is the most relevant way to evaluate the environmental properties of construction materials which are in direct or indirect contact with soil and ground water. This is also recognised in the ongoing development of criteria and methods for evaluation of the health, hygiene and environmental requirements for construction products, mandated by the European Commission. In this respect, it is important to determine the environmental properties of recycled concrete aggregate (RCA), as a high level of recycling is desirable for this waste material because of the high volumes generated.

Regarding laboratory testing a variety of leaching methods exist. In order to choose the relevant test, it is important to decide which parameters should be revealed by the test to get the desired information such as the effect of $\mathrm{pH}$, maximum release, equilibrium concentrations and diffusion controlled release. Furthermore, to interpret the obtained release data in a correct way, it is beneficial to understand the fundamental leaching processes, which depend on the speciation of the elements in the solution and the solid phase. These leaching processes are, in turn, causing the partitioning of chemical species between the solid and the aqueous phase, and they can often be described by processes such as ion exchange/sorption,

\footnotetext{
* Corresponding author. Tel.: +47 229655 55; fax: +47 22699438. E-mail address: Christian.engelsen@sintef.no (C.J. Engelsen).
}

complexation, precipitation/dissolution and incorporation into a mineral phase [1]. Such reactions may be described using equilibrium constants derived from thermodynamic data. The equilibrium concentrations can be calculated by the law of mass action. When the system contains several species, a number of equations are needed to describe the processes. To solve the set of equations, numerical models are usually applied.

In leaching tests, where the suspension is brought towards chemical equilibrium before determining the partitioning of the species between the solid and liquid phases, the key factors will be the $\mathrm{pH}$ of the suspension and the liquid to solid ratio (L/S). The former parameter strongly affects the released quantities and it is thus important to cover a wide $\mathrm{pH}$ range with an equilibrium leaching test, as recognised in earlier studies [2-4]. In relation to a field scenario, the strong alkaline nature of concrete materials, the possible presence of concrete at different degrees of carbonation and the varying external $\mathrm{pH}$ encountered at the field site (low ionic strength rain fall, acid soil water, ground water, etc.) support that the released content must be determined over a wide $\mathrm{pH}$ range.

The leaching of the major elements $\mathrm{Al}, \mathrm{Ca}, \mathrm{Fe}, \mathrm{Mg}, \mathrm{Si}$ and $\mathrm{S}$ from crushed concrete is described in our recent study [2] where also a geochemical speciation model was presented. An adequate description was given for the solubility controlling phases in the $\mathrm{pH}$ range 213 at the fixed liquid to solid ratio of $10(\mathrm{~L} / \mathrm{kg})$. In the present study, the leaching of metals of environmental concern was studied, including element forming cations ( $\mathrm{Cd}, \mathrm{Cu}, \mathrm{Mn}, \mathrm{Ni}, \mathrm{Pb}$, and $\mathrm{Zn}$ ) and oxyanions ( $\mathrm{Cr}$, Mo and $\mathrm{V}$ ) in solution. Regarding the $\mathrm{pH}$ dependent 
Table 1

Properties of the sample batches.

\begin{tabular}{|c|c|c|c|c|c|c|c|}
\hline & \multicolumn{7}{|l|}{ Sample $^{\mathrm{a}}$} \\
\hline & A & B & $\mathrm{C}$ & $\mathrm{D}$ & E1 & E2 & E3 \\
\hline Particle size $(\mathrm{mm})^{\mathrm{a}}$ & $0-10$ & $10-20$ & $10-38$ & $20-120$ & $0-4$ & $4-8$ & $8-16$ \\
\hline Classification (Type) $^{\mathrm{b}}$ & 2 & 2 & 2 & 1 & 1 & 1 & 1 \\
\hline Material $\mathrm{pH}^{\mathrm{c}}$ & 11.6 & 11.9 & 12.0 & 12.6 & 12.7 & 12.7 & 12.8 \\
\hline Total carbon (\%) & 2.51 & 1.56 & 1.78 & 0.37 & 0.32 & 0.25 & 0.21 \\
\hline Total inorganic carbon (\%) ${ }^{\mathrm{d}}$ & 0.92 & 0.88 & 0.88 & 0.13 & 0.060 & 0.039 & 0.027 \\
\hline Total organic carbon (\%) & 1.59 & 0.68 & 0.90 & 0.24 & 0.26 & 0.21 & 0.18 \\
\hline Solid humic substances $(\mathrm{g} / \mathrm{kg})^{\mathrm{e}}$ & 0.27 & 0.12 & 0.11 & n.r. ${ }^{h}$ & n.r. ${ }^{h}$ & n.r. ${ }^{\mathrm{h}}$ & n.r. ${ }^{\mathrm{h}}$ \\
\hline Dissolved humic fraction ${ }^{f}$ & $0.03-0.15$ & $0.03-0.15$ & $0.03-0.15$ & n.r. ${ }^{\text {h }}$ & n.r. ${ }^{\text {h }}$ & n.r. ${ }^{h}$ & n.r. ${ }^{\mathrm{h}}$ \\
\hline Hydrous ferric oxide $(\mathrm{kg} / \mathrm{kg})^{\mathrm{g}}$ & 0.013 & 0.016 & 0.010 & 0.012 & 0.023 & 0.016 & 0.014 \\
\hline Acid solubility (\%) & 17.7 & 13.7 & 13.9 & 12.7 & 28.1 & 17.9 & 12.8 \\
\hline
\end{tabular}

a Samples A, B, C and D were collected at a recycling plant. Samples E1-E3 were prepared in laboratory using standard Portland cement. Prior to experiments, the samples were further ground, see text.

b According to Norwegian declaration system [22].

c $\mathrm{pH}$ determined in the eluate of the leaching test with no addition of acid and base.

d Determined as total inorganic carbon (TIC) by the TOC analyser and verified by TGA-MS. For sample A, the TGA-MS values were used, see Section 2.3 .

e Solid content of humic and fulvic substances derived from selective extractions and used in the model, see Section 2.4.

${ }^{f}$ Fractions of the dissolved organic carbon (DOC) that contain humic substances, see Section 2.4

g Hydrous ferric oxide (HFO) content available in the material and used in the model.

h Not relevant parameter.

leaching from cement based materials some relevant studies are available [4-6]. In our previous [2] and in the present study we expand the $\mathrm{pH}$ range compared to the earlier reported studies in order to cover the most acidic region as well as the alkaline $\mathrm{pH}$ above 13 . A $\mathrm{pH}$ around 2 (not encountered at field site) has been included in order to determine the available quantity of each constituent which is used as input in the geochemical speciation model.

In order to identify the predominating leaching processes, the geochemical speciation and transport modelling framework ORCHESTRA [7] was applied on the metal concentrations in the leachates. ORCHESTRA is integrated in the data management tool LeachXS (Leaching Expert System) [8] and the selected elements for modelling were $\mathrm{Cu}, \mathrm{Ni}, \mathrm{Cr}$ and $\mathrm{Mo}$ as they cover both cations and oxyanions. At high $\mathrm{pH}$, the hydrate phases of $\mathrm{C}-\mathrm{S}-\mathrm{H}, \mathrm{AFt}$ and $\mathrm{AFm}^{1}$ have the ability to bind oxyanions and metal cations in different ways as reviewed by Cornelis et al. [9]. Oxyanionic species (e.g. $\mathrm{CrO}_{4}{ }^{2-}$ and $\mathrm{MoO}_{4}{ }^{2-}$ ) may be incorporated in ettringite and monosulphate [1012] by substituting $\mathrm{SO}_{4}{ }^{2-}$. Moreover, early studies of the cation exchange capacity of $\mathrm{C}-\mathrm{S}-\mathrm{H}$ were carried out on 11- $\AA$ tobermorite $[13,14]$ and $\mathrm{Cd}^{2+}, \mathrm{Cu}^{2+}, \mathrm{Mn}^{2+}, \mathrm{Pb}^{2+}$ and $\mathrm{Zn}^{2+}$ were reported to replace $\mathrm{Ca}^{2+}$ by ion exchange. More recent studies seem to confirm the metal cation uptake to $\mathrm{C}-\mathrm{S}-\mathrm{H}$, although the specific binding mechanisms are not clear $[15,16]$. The model setup used in this study has been developed by Engelsen et al. [2]; the equilibrium constants reported by Lothenbach et al. [17] were used for the main cement hydrate phases. Recently, Matschei et al. [18] have suggested revised equilibrium constants for hydrogarnet $\left(\mathrm{C}_{3} \mathrm{AH}_{6}\right)$ and monosulphoaluminate $\left(\mathrm{C}_{4} \mathrm{AS}^{\prime} \mathrm{H}_{12}\right){ }^{1}$ These constants were included in the present study and a modified speciation description of the major elements will be given in the high alkaline region. In leaching studies of other materials, such as soil and municipal solid waste incinerator bottom ash, geochemical modelling has proven to give a significant insight to this complex matter $[1,19,20]$.

In the present study, the computer modelled leaching was compared with the laboratory leaching. A close match will support the subsequent speciation predictions, i.e. the distribution of an element among solid mineral phases and the liquid phase. The study was part of the Norwegian Road Recycling R\&D program [21] and the leaching properties were examined for crushed concrete sam-

\footnotetext{
${ }^{1}$ Short hand cement chemistry notation: $\mathrm{C}=\mathrm{CaO} ; \mathrm{S}=\mathrm{SiO}_{2} ; \mathrm{S}^{\prime}=\mathrm{SO}_{3} ; \mathrm{A}=\mathrm{Al}_{2} \mathrm{O}_{3}$; $\mathrm{m}=$ mono substituted; $\mathrm{F}=\mathrm{Fe}_{2} \mathrm{O}_{3} ; \mathrm{t}=$ tri substituted; $\mathrm{H}=\mathrm{H}_{2} \mathrm{O}$.
}

ples cast in the laboratory as well as for samples collected at different recycling sites in the field.

\section{Materials and methods}

\subsection{Materials}

The samples tested were the recycled concrete aggregate samples (RCA) listed in Table 1. There are two main categories of RCA in Norway [22]; Type 1 and Type 2 which need to fulfill different requirements for unbound and bound use. For unbound use, the materials of Type 1 are required to contain more than $96 \%$ by weight of crushed concrete and/or natural aggregates. In the Type 2 category, the materials must consist of more than $90 \%$ of concrete, masonry and natural aggregates. In both categories the content of recycled asphalt is limited to less than $5 \%$. The sample batches undertaken in this study belonged to both categories as given in Table 1.

Sample batches A, B and C, each of $500 \mathrm{~kg}$, were collected from the recycling facility BA Gjenvinning AS in Oslo. They were partly carbonated as they originated from old concrete and masonry buildings. Sample batch D originated from a section of the highway E6 (25 km south of Oslo) that was constructed with concrete pavement in the beginning of the 1980s. Due to reconstruction, the concrete pavement was demolished, crushed and fractionated into a grain size of $20-120 \mathrm{~mm}$ on site. The material was then used in test segments of the sub base layer in the entrance lane to the reconstructed highway [23]. Sample batch D (20-120 mm) was taken from these test fields on the day of construction.

The laboratory samples (E1-E3) were prepared with Portland cement (Norcem Industrisement, CEM I), natural Norstone AS aggregate and admixture (super plasticizer SSP 2000). The clinker content was $94 \%$ and the rest was interground gypsum (4.4\%), limestone filler $(<0.4 \%)$, iron sulphate $(0.6 \%)$ and triethanolamin as grinding aid $(0.06 \%)$. The concrete mix was prepared with a water/ cement ratio of 0.6 , a cement content of $325 \mathrm{~kg} / \mathrm{m}^{3}$, an admixture content of $0.15 \%$ of the cement weight and it was cast in steel mould cubes of $100 \times 100 \times 100 \mathrm{~mm}$. Concrete properties of fresh and hardened material were determined according to the standards EN 12350 and 12390 . The casting, curing and hardening were conducted in the concrete laboratory of Norcem A.S. Following a hardening period of 150 days in the climate chamber $\left(20^{\circ} \mathrm{C}\right.$ and $90 \%$ relative humidity), sufficient numbers of cubes were size reduced and fractionated into sample batches E1, E2 and E3 with the particle size 
ranges $0-4 \mathrm{~mm}, 4-8 \mathrm{~mm}$ and $8-16 \mathrm{~mm}$ respectively, as listed in Table 1.

In this study the term material $\mathrm{pH}$ refers to the equilibrium $\mathrm{pH}$ in the leaching suspension (L/S of 10 ) where no acid or base has been added, see Section 2.2. An indication of the carbonation levels of the samples was obtained from the material $\mathrm{pH}$ values, and significant lower values were found for samples A, B and C compared to the carbonation-free samples $\mathrm{D}$ and $\mathrm{E}$, as shown in Table 1 . This was also in agreement with the origin of the sample batches described above. Due to the L/S of 10 applied in the leaching test, the material $\mathrm{pH}$ of $\mathrm{D}$ and $\mathrm{E}$ was significantly lower than the $\mathrm{pH}$ normally found in Portland cement concrete pore water $(\sim 13.5)$. The carbonation levels of the samples were also verified by carbon analyses, thermogravimetric analyses (TGA) online-coupled with a mass spectrometer (MS) and X-ray diffraction (XRD) measurements as shown in our previous study [2]. The results (expressed as total inorganic carbon) were in accordance with the material $\mathrm{pH}$, as shown in Table 1. Sample A was the most carbonated sample whereas samples D and $\mathrm{E}$ had low inorganic carbon contents.

Total concentrations of the minor and trace constituents, determined in all samples after acid digestion (see Section 2.3), are given in Table 2. As samples E1-E3 were prepared with the same cement, the total element content was only determined in sample E1. The principle phase composition of the clinker is also given in Table 2. As shown in our previous study [2], the mineralogy of samples A, D and E1 was dominated by quarts, feldspars (albite and microcline) and to some extent phyllosilicate (chlorite) due to the contribution from the aggregates. Portlandite was identified only in samples D and E1 whereas a significant calcite peak was identified in sample A. Identification of mineral phases in the binder of the samples (other than calcite and portlandite) was difficult in samples A and D due to their complex characters. Based on TGA and differential thermal analyses, carried out by Heidelberg Technology Centre, the weight loss and the reaction heat indicated the presence of ettringite in sample D.

The cement paste content in sample E1 was increased from $28 \%$ to $\sim 52 \%$ by passing the sample through a $90 \mu \mathrm{m}$ sieve. Since this sample had a significantly increased paste content in the fine fraction, mineral phase quantification using Rietveld Refinement was carried out. This was conducted for the intact sample (sieved at $90 \mu \mathrm{m}$ ) and also after the paste had been removed by dissolving it in $\mathrm{HCl}$, i.e. the aggregate residue was analysed. The results are given in Table 3. Note that the presence of several of the mineral phases is uncertain (see Table 3) and including them in the quantifications induces uncertain-

Table 2

Minor and trace element concentrations in the samples determined by ICP-OES.

\begin{tabular}{|c|c|c|c|c|c|}
\hline \multirow[t]{2}{*}{ Element } & \multicolumn{5}{|c|}{ Sample (mg/kg) } \\
\hline & A & B & C & $\mathrm{D}$ & E1 \\
\hline $\mathrm{Cu}$ & 43 & 35 & 49 & 12 & 24 \\
\hline $\mathrm{Ni}$ & 32 & 34 & 32 & 14 & 15 \\
\hline $\mathrm{Pb}$ & 62 & 42 & 37 & 31 & 12 \\
\hline $\mathrm{Cd}$ & $<0.7$ & $<0.7$ & $<0.7$ & $<0.7$ & $<0.6$ \\
\hline Mn & 590 & 635 & 610 & 393 & 272 \\
\hline $\mathrm{Zn}$ & 553 & 144 & 171 & 45 & 53 \\
\hline $\mathrm{Cr}$ & 116 & 82 & 93 & 69 & 49 \\
\hline Mo & 8.7 & 5.5 & 4.4 & 6.0 & $<3.7$ \\
\hline V & 84 & 92 & 80 & 53 & 35 \\
\hline \multicolumn{6}{|c|}{ Bogue composition ${ }^{\text {a }}$} \\
\hline $\mathrm{C}_{3} \mathrm{~S}$ & & & & & 51 \\
\hline $\mathrm{C}_{2} \mathrm{~S}$ & & & & & 18 \\
\hline $\mathrm{C}_{3} \mathrm{~A}$ & & & & & 7.7 \\
\hline $\mathrm{C}_{4} \mathrm{AF}$ & & & & & 10 \\
\hline
\end{tabular}

Cement clinker composition used in samples E1-E3 was analysed by X-ray fluorescence (XRF) and the estimated Bogue composition is given for the clinker.

a Mineral phase composition of the clinker used for sample E. Estimations were made on the basis of the XRF values as input: $\mathrm{A}=\mathrm{Al}_{2} \mathrm{O}_{3}, \mathrm{C}=\mathrm{CaO}, \mathrm{F}=\mathrm{Fe}_{2} \mathrm{O}_{3}, \mathrm{~S}=\mathrm{SiO}_{2}$.
Table 3

XRD phase quantification of the fine fraction $(<90 \mu \mathrm{m})$ of sample E1 using Rietveld Refinement.

\begin{tabular}{|c|c|c|}
\hline Mineral & $\begin{array}{l}\text { E1(aggregate and } \\
\text { paste }(\sim 1+1))\end{array}$ & $\begin{array}{l}\text { E1* } \\
\text { (aggregate) }\end{array}$ \\
\hline Albite, $\mathrm{NaAlSi}_{3} \mathrm{O}_{8}$ & 20 & 34 \\
\hline Belite, $\mathrm{Ca}_{2} \mathrm{SiO}_{4}$ & $3.3^{\mathrm{a}}$ & n.d $d^{b}$. \\
\hline Biotite, $\mathrm{K}\left(\mathrm{Mg}, \mathrm{Fe}^{\mathrm{II}}\right)_{3}\left[(\mathrm{OH}, \mathrm{F})_{2}:(\mathrm{Al}, \mathrm{Fe}) \mathrm{Si}_{3} \mathrm{O}_{10}\right]$ & $1.2^{\mathrm{a}}$ & $3.8^{\mathrm{a}}$ \\
\hline Calcite, $\mathrm{CaCO}_{3}$ & 3.8 & n.d. \\
\hline Chlorite, $(\mathrm{Mg}, \mathrm{Al}, \mathrm{Fe})_{6}\left[(\mathrm{OH})_{8}:(\mathrm{Si}, \mathrm{Al})_{4} \mathrm{O}_{10}\right]$ & $2.2^{\mathrm{a}}$ & $5^{\mathrm{a}}$ \\
\hline Cordierite, $\mathrm{Mg}_{2} \mathrm{Al}_{4} \mathrm{Si}_{5} \mathrm{O}_{18}$ & $1.0^{\mathrm{a}}$ & $3.4^{\mathrm{a}}$ \\
\hline Diopside, $\mathrm{CaMg}\left(\mathrm{SiO}_{3}\right)_{2}$ & $5.1^{\mathrm{a}}$ & $2.7^{\mathrm{a}}$ \\
\hline Ettringite, $\mathrm{Ca}_{6} \mathrm{Al}_{2}\left(\mathrm{SO}_{4}\right)_{3}(\mathrm{OH})_{12} \cdot 26 \mathrm{H}_{2} \mathrm{O}$ & 4.2 & n.d. \\
\hline Gypsum, $\mathrm{CaSO}_{4} \cdot 2 \mathrm{H}_{2} \mathrm{O}$ & $2.9^{\mathrm{a}}$ & n.d. \\
\hline Maghemite, $\mathrm{Fe}_{2} \mathrm{O}_{3}$ & $0.2^{\mathrm{a}}$ & $1.4^{\mathrm{a}}$ \\
\hline Microcline, $\mathrm{KAISi}_{3} \mathrm{O}_{8}$ & 8.7 & 18 \\
\hline Portlandite, $\mathrm{Ca}(\mathrm{OH})_{2}$ & 10.2 & n.d. \\
\hline Quartz, $\mathrm{SiO}_{2}$ & 16 & 31 \\
\hline Calcium silicate hydrates (C-S-H) & $21^{\mathrm{c}}$ & n.d. \\
\hline Total & $\sim 100$ & $\sim 100$ \\
\hline
\end{tabular}

XRD measurements on the aggregate residue after dissolution of the sample in $\mathrm{HCl}$ are indicated $\mathrm{E} 1^{*}$.

a Regarded as an inferior (uncertain) phase in the qualitative evaluation.

b n.d. = not detected.

c Based on the estimated amorphous content.

ties in the final phase contents. In addition, semi-quantification of the C-S-H phases was used in the refinement based on the "hump" caused by amorphous compounds in the X-ray diffractogram. Note that due to the complexity of the sample, it was not possible to quantify the carboaluminate phases that most likely are present. This will also influence the Rietveld refinement results. However, given the fact that the cement paste content was roughly $50 \%$, the quantification of the main aggregate phases (albite, microcline and quartz) was reasonable, as the contents of these phases appeared to be about twice as high in the aggregate residue compared to the intact sample (paste and aggregate), as shown in Table 3.

\subsection{Sample preparation and leaching test}

Detailed description of the splitting and size reduction procedure is given elsewhere [2]. In short, all sample batches were converted into laboratory and test samples following the standards EN 932-2 and EN 15002. Sample batches A, B, C and D were reduced into appropriate test samples of particle sizes less than $1 \mathrm{~mm}$ by using an automatic agate mortar mill. Due to the coarse particle size of B-D, pre-crushing in a jaw crusher was necessary before applying the agate mortar mill. Sample batch E (ten cubes) were crushed after 150 days curing and hardening. This was carried out by using the compressive strength machine first, in order to break the cubes into smaller pieces, and then apply a jaw crusher. Following this, samples E1, E2 and E3 were prepared by sieving the crushed material into the various particle size fractions; $0-4 \mathrm{~mm}, 4-8 \mathrm{~mm}$ and $8-16 \mathrm{~mm}$, respectively. For the leaching test, these samples were further reduced in the agate mortar mill to a particle size less than $1 \mathrm{~mm}$. Sample E3 was pre-crushed with granite blocks in order to have an appropriate size for the agate mortar. Test samples of $80-100 \mathrm{~g}$ (15-20 pieces) were thereafter prepared for all samples (A-E), again according to the splitting procedure in EN 932-2. The grinding to obtain particle sizes less than $1 \mathrm{~mm}$, was conducted prior to the leaching tests. All steps in the preparation of the samples were conducted with care in order to ensure that no fine particles were lost. Furthermore, to minimize contamination of the samples, the sample reductions were carried out on polyethylene (PE) foil and the splitting equipment of metal was also covered with PE foil.

The acid soluble part, as measured with the procedure described below and reported in Table 1, is assumed to represent the cement paste content. In general, this assumption is only valid for samples with inert aggregates. However, calculations showed that this 
assumption was reasonable for sample E1 [2]. The procedure for measuring the acid solubility is based on a modified procedure of the Nordtest method [24]. In short, the test samples were ground to particle sizes less than $125 \mu \mathrm{m}$ in a stainless steel MFC mill (Culatti AG, Zürich, Switzerland) and $4 \mathrm{~g}$ of ground material was accurately weighed into a $250 \mathrm{ml}$ beaker followed by addition of $3 \mathrm{ml}$ of ethanol and $150 \mathrm{ml}$ of deionized water (>18.2 $\mathrm{M} \Omega \mathrm{cm}$ ). $10 \mathrm{ml}$ of concentrated nitric acid (65\% w/w analytical grade) was gently added to the beaker during agitation of the water suspension using a magnetic stirrer. The suspension was agitated for $30 \mathrm{~min}$. Insoluble matter was then determined gravimetrically after sedimentation $(>5 \mathrm{~h})$, filtration and drying. From this, the acid soluble part was calculated and referred to as the cement paste content. Homogeneity of the laboratory and test samples was controlled with respect to the variation in the cement paste content in a series of test samples from the same sample batch. Insignificant variation was found for all test sample series and proved the consistency of the splitting and size reduction procedure [2].

The $\mathrm{pH}$ dependent batch leaching test CEN/TS 14429 was used [25]. The principle of this method is to assess the leaching behaviour of inorganic species in terms of equilibrium concentrations at different $\mathrm{pH}$ values. In order to comply with the representative mass in EN 15002, test portions of approximately $60 \mathrm{~g}$ were used. In each leaching test a minimum of 9 similar suspensions were prepared with deionized water $(>18.2 \mathrm{M} \Omega \mathrm{cm}$ ) in $1000 \mathrm{ml}$ acid cleaned HDPE vessels. Necessary quantities of 1.8-3.6 $\mathrm{M} \mathrm{HNO}_{3}$ (Suprapur) or $1.0 \mathrm{M}$ $\mathrm{NaOH}$ (analytical grade) were added to the suspensions in order to achieve end $\mathrm{pH}$ values between 2 and 13.5. The approximate quantities of acid and base additions were determined in screening tests prior to the leaching tests. The final L/S used was $10 \pm 0.3 \mathrm{ml} / \mathrm{g}$ and the suspensions were equilibrated for $48 \mathrm{~h}$ in an end-over-end roller followed by sedimentation overnight. Following this, the $\mathrm{pH}$ and the conductivity were determined, before the suspensions were filtrated through $0.45 \mu \mathrm{m}$ membrane filters. The $\mathrm{pH}$ measured in the suspension with no acid/base addition is referred to as the material $\mathrm{pH}$, see Table 1 . The filtrates were divided into two parts: the first part was untreated (non-acidified) while the second part was acidified $\left(\mathrm{pH}<2\right.$ with Suprapur $\mathrm{HNO}_{3}$ ). The parts were kept under freezing and cooling conditions, respectively, before the chemical analysis (see below). The leaching test for sample A was carried out three times. The relative standard deviations in the concentration of metal cations ( $\mathrm{Cd}, \mathrm{Cu} \mathrm{Ni}, \mathrm{Mn}, \mathrm{Pb}$ and $\mathrm{Zn}$ ) and oxyanions ( $\mathrm{Cr}$, Mo and $\mathrm{Ni}$ ) were below $31 \%$ and $20 \%$, respectively (for concentrations above 3 times the limit of detection).

\subsection{Chemical analysis}

\subsubsection{Leachates}

Inductively coupled plasma-optical emission spectrometry using a Varian Vista ICP-OES (Varian Ltd, Australia) was used to determine major elements ( $\mathrm{Al}, \mathrm{Ba}, \mathrm{Ca}, \mathrm{Fe}, \mathrm{K}, \mathrm{Mg}, \mathrm{Na}, \mathrm{S}$ and $\mathrm{Si}$ ), minor and trace metal cations ( $\mathrm{Cd}, \mathrm{Cu}, \mathrm{Mn}, \mathrm{Ni}, \mathrm{Pb}$ and $\mathrm{Zn}$ ) and elements that under certain conditions form oxyanions (As, B, Cr, Mo, Sb, Se and V). The anions $\mathrm{Cl}^{-}$, $\mathrm{Br}^{-}, \mathrm{SO}_{4}{ }^{2-}$ and $\mathrm{F}^{-}$were determined by ion chromatography (Dionex IC25, CA, US) and the dissolved organic carbon (DOC) and dissolved inorganic carbon (DIC) were measured by a total organic carbon (TOC) analyser (Shimadzu 9000a). Measurements of pH in the leachates were conducted on a computerized titration system (Metrohm Basic Titrino 794), while the conductivity was measured with an ion analyser (Hach Sension analyser). The measured concentrations of all elements in the leachates were used in the geochemical model (see Section 2.4).

\subsubsection{Solid samples}

The same elements which were determined in the leachates by ICP-OES were also determined in the solid samples by the same technique after the materials were ground to particle sizes less than $125 \mu \mathrm{m}$ in the agate mortar mill and decomposed by a mixture of concentrated $\mathrm{HNO}_{3}$ and $\mathrm{HClO}_{4}$ (in proportion of 20:1) in an autoclave at $190{ }^{\circ} \mathrm{C}$ for $10 \mathrm{~h}$. The residual matter was digested with $\mathrm{HNO}_{3} / \mathrm{HF} /$ $\mathrm{HClO}_{4}$ (in proportion of 10:9:1). The total carbon (TC) content in the solid samples was determined by combustion and IR detection (Eltra CS 800, Neuss, Germany). Total inorganic carbon (TIC) content in the solids was determined (as $\mathrm{CO}_{2}$ ) by a TOC analyser (Shimadzu SSM) and acidification with concentrated $\mathrm{H}_{3} \mathrm{PO}_{4}$. Inorganic carbon (as carbonate) was determined by using a TGA7 thermogravimetric analyser (Perkin Elmer) with TAC 7/DX thermal controller (Perkin Elmer). The heating gradient was $5{ }^{\circ} \mathrm{C} / \mathrm{min}$ in either nitrogen or oxygen atmosphere and sample weights of $40-80 \mathrm{mg}$ fine pulverised $(<125 \mu \mathrm{m})$ solid material were used. The outlet gas was analysed online for $\mathrm{CO}_{2}$ using a HPR-20 quadrupole mass spectrometer (Hiden Analytical). The TOC in the samples was estimated from the difference between the measured TC and TIC. Total concentrations of the major elements in the cement used for sample E were determined by X-ray fluorescence spectrometry (Philips PWW 2404).

The solid concentration of humic acid (HA) and fulvic acid (FA) in samples A-C was quantified by a batch procedure [26], which is derived from the procedure currently recommended by the International Humic Substances Society (IHSS) for solid samples [27]. The procedure is based on the solubility behaviour of HA (flocculation at $\mathrm{pH}<1$ ) and the adsorption of FA to a polymer resin (DAX-8). The content of amorphous and crystalline iron (hydr)oxides was determined by dithionite extraction, whereas the amorphous part was estimated by ascorbate extraction according to Kostka and Luther III [28]. The aluminium (hydr)oxides in the samples were determined by oxalate extractions [29].

The ICP-OES, ion chromatography, selective extractions, TIC and TOC (leachates) analyses were carried out at the Energy Research Centre of the Netherlands (ECN). The X-ray fluorescence (XRF) and TC determinations were conducted at Norcem AS. Leachate preparations and other measurements were conducted at SINTEF or University of Oslo, Department of Chemistry.

\subsection{Geochemical modelling and input parameters}

The data handling and modelling software LeachXS (Leaching Expert System) version 1.4.0.1 was used [8]. The system has incorporated the speciation and transport modelling framework ORCHESTRA, for which mineral saturation, solution speciation and sorption processes can be calculated based on equilibrium models and corresponding thermodynamic data [7]. An extended version of the thermodynamic database MINTEQA2 [30] is incorporated in ORCHESTRA for utilisation in highly alkaline systems.

The equilibrium concentrations of the measured species in the leachates from the $\mathrm{pH}$ dependent test were used as input data in the model (see Section 2.3). The approach will take into account any leaching contribution from the aggregate part, although this is considered to be significantly smaller than the leaching from the cement paste [2]. In addition, the reactive carbon (humic substances; HA and FA) as part of the measured organic carbon (when relevant) and the amount of hydrous ferric oxide (HFO) sorption sites had to be specified in the model as input data. The non-ideal competitive adsorption (NICA)-Donnan model [31,32] was used to calculate the reactive carbon interactions (binding to HA and FA). This adsorption model was originally developed for natural organic matter in soil and surface water, but recent studies demonstrate the applicability to waste materials [33,34]. The sum of HA and FA was used in the model as HA interactions. These interactions were only taken into account for the Type 2 samples in Table $1(\mathrm{~A}-\mathrm{C})$ due to their origin and age. For input to the model it was assumed that $50 \mathrm{wt} . \%$ of the measured HA and FA was carbon (see Table 1). Note that the experimental values derived $(0.11-0.27 \mathrm{~g} / \mathrm{kg})$ are roughly within the same concentration region anticipated in our previous study $(0.25-0.50 \mathrm{~g} / \mathrm{kg})$ [2]. Based on similar extractions of fresh and aged municipal solid waste 
incinerator (MSWI) bottom ash samples [34], it was assumed that 2$12 \%$ of the total solid humic substances (10-50\% of FA fraction) was released, which constituted $3-15 \%$ of the DOC measured in the leachates, see Table 1.

Specific binding of metal cations and (oxy)anions to hydrous ferric oxide (HFO) was calculated using the generalised two-layer model of Dzombak and Morel [35]. The amount of available sorbent mineral was determined by selective chemical extractions (see Section 2.3) and leached concentrations of $\mathrm{Fe}$ and $\mathrm{Al}$ at $\mathrm{pH}$ less than 2 [2]. Based on the extracted or leached concentrations of $\mathrm{Al}$ and Fe respectively, the total HFO was calculated and expressed as kg sorbent pr. kg dry material as required in the model, see Table 1 . Amorphous aluminium hydroxide was treated as a sorbent mineral in the same way as amorphous iron oxide. This approach has been used for soil and bottom ash materials $[1,20]$. For the relevant HFO surface complexation constants we refer to Dzombak and Morel [35].

The minerals selected in this study are given elsewhere [2]. The reaction equilibrium constants in the thermodynamic database of Leach XS were used in the model. Ion activity coefficients were calculated using Davies equation. Oxidizing conditions were assumed in the system and $\mathrm{pH}+\mathrm{pe}=15$ was used in the simulations. The predicted leaching was compared with the laboratory leaching data. The first criterion used in the comparison was to evaluate if the model was able to simulate the characteristic $\mathrm{pH}$ dependent leaching patterns obtained in laboratory experiments. The second criterion was to compare the measured and simulated leached metal concentrations; a difference of less than half an order of magnitude is considered as an adequate match.

\section{Results and discussion}

\section{1. $p H$ dependent release of metal cations}

In Fig. 1 the $\mathrm{pH}$ dependent release of $\mathrm{Cd}, \mathrm{Cu}, \mathrm{Mn}, \mathrm{Ni}, \mathrm{Pb}$ and $\mathrm{Zn}$ is shown. For sample E only E2 is shown as the E1 and E3 showed similar release patterns. The overall leaching patterns for the elements were found to be the same for all materials. The data set had some limitations, particularly for $\mathrm{Cd}$ and $\mathrm{Pb}$ at $\mathrm{pH}$ above 7 , because the released quantities were below the limit of detection (LOD).

At very high $\mathrm{pH}$ (alkaline) a significant difference in the leaching behaviour was found between partly carbonated $(A-C)$ and the carbonation-free samples ( $\mathrm{D}$ and E2). In Fig. 1 it can be seen that $\mathrm{Cu}, \mathrm{Ni}$ and $\mathrm{Zn}$ were more retained in the latter samples when the $\mathrm{pH}$ was raised above the material $\mathrm{pH}$. The difference between the released $\mathrm{Cu}$ from samples B and E2 at the highest pH is more than one order of magnitude, whereas the available quantity (low $\mathrm{pH}$ ) is approximately the same. This effect can also be seen for $\mathrm{Ni}$; an increase above the material $\mathrm{pH}$ did not influence the Ni concentrations in the leachates from $\mathrm{D}$ and $\mathrm{E} 2$, whereas Ni leached from sample A was approaching the calculated solubility for $\mathrm{Ni}(\mathrm{OH})_{2}$ in the alkaline $\mathrm{pH}$ area. Such immobilisation of metals is attributed to the intact cement paste. Thus, the solubility is dictated by the presence or absence of the cement hydrate phases (hydrated calcium silicates, hydrated calcium aluminates, etc.). The amount of the different hydrate phases in the $\mathrm{pH}$ range 11.5-13.5 will also change due to their solubility products as shown in [36]. This in turn will affect the metals bound to these phases and it explains why the released amount of certain elements from a carbonation-free sample also increases at elevated $\mathrm{pH}$ (e.g. $\mathrm{Cu}, \mathrm{Pb}$ and $\mathrm{Zn}$ ), see further discussion in 3.4. For (oxy)anions this will be even more pronounced as will be shown in the next section. In addition, $\mathrm{Zn}$ can be controlled by $\mathrm{CaZn}_{2}(\mathrm{OH})_{6} \cdot 2 \mathrm{H}_{2} \mathrm{O}$ (calcium zincate) at material $\mathrm{pH}$ [37]. In this reaction $\mathrm{Zn}(\mathrm{OH})_{3}{ }^{-}$is precipitated as calcium zincate. Analogue reactions for $\mathrm{Cu}, \mathrm{Pb}$ and $\mathrm{Ni}$ could also be the case, although solubility constants are missing.

As the $\mathrm{pH}$ was decreased in the leaching experiments (Fig. 1), low solubility was encountered for all the metals in the $\mathrm{pH}$ range 7-10.
The concentration of $\mathrm{Cu}$ at its solubility minimum was orders of magnitude higher for samples A-C compared to D and E2, most likely due to the dissolved reactive organic carbon (humic substances) in the former samples. This was also predicted by the speciation model as will be shown in a later section. It was also found that humic substances were present in small amounts in the RCA samples of more mixed compositions (Type 2; see Table 1), thus resulting in an enhanced leaching of copper.

In the most acidic region of Fig. 1, i.e. $\mathrm{pH} \sim 1-2$, the leached contents for all elements are at their maxima and represent the available contents (maximum leachability) as the paste was degraded. It can be seen that the leached quantities are below the total concentration levels in Table 2, which were determined in decomposed samples, i.e. with contribution from both paste and aggregate. However, assuming that the paste was the main contributor to the constituent release in these leaching experiments, a fingerprint of the "paste leachability" can be obtained on the basis of the ratio of the leached concentrations and total concentration in the paste (recalculated from total concentrations in the cement). This was carried out for sample E1 and is shown in Fig. 2.

The leachabilities of $\mathrm{Ca}$ and $\mathrm{S}$ were included in the figure in order to indicate the degradation of the cement paste. For these elements the leachability increased rapidly as the $\mathrm{pH}$ decreased from material $\mathrm{pH}$ due to the decalcification of calcium silicate hydrates $(\mathrm{C}-\mathrm{S}-\mathrm{H})$, dissolution of portlandite and calcium sulphoaluminate hydrates (e.g. ettringite). At about $\mathrm{pH} 9.5,70-80 \%$ of the leachable contents of $\mathrm{Ca}$ and $\mathrm{S}$ were released into solution. The rapid increase in leachability of Ca is initially caused by the dissolution of portlandite as can be seen in Fig. 2 . In contrast, the release of $\mathrm{Na}$ was virtually $\mathrm{pH}$ independent.

The strong $\mathrm{pH}$ dependence picture can also be seen for the minor and trace elements in Fig. 2 as well as large differences between the constituents in the same material. The leachability of $\mathrm{Zn}$ reached its minimum (0.016\%) at $\mathrm{pH} 9.5$. At this $\mathrm{pH}$ it is most likely that a secondary precipitated mineral phase and/or sorption to reactive surfaces (e.g. hydro ferric oxide) were controlling the solubility. The calculations appeared to be relatively precise, as maximum leachabilities stabilized in the range $85-136 \%$ of the element content in the paste. Leachability larger than $100 \%$ indicates contribution from other sources than the cement paste, i.e. mainly aggregate. Thus, the results demonstrate that the measured leaching mainly originated from the paste, as expected.

\section{2. $\mathrm{pH}$ dependent release of $\mathrm{Cr}$, Mo and $\mathrm{V}$}

The leaching patterns for elements that form oxyanions will in principle be different from the leaching patterns of the metal cations, due to the negative charge of the oxyanions. In the oxyanions, the chemical bonding between the metal and oxygen is covalent. Elements that are close to oxygen in electronegativity tend to form oxyanions, for example the transition metals Mo and $\mathrm{Cr}$ form $\mathrm{MoO}_{4}{ }^{2-}$ and $\mathrm{CrO}_{4}{ }^{2-}$, respectively [38]. In Fig. 3, the $\mathrm{pH}$ dependent release of the transition metals $\mathrm{Mo}, \mathrm{Cr}$ and $\mathrm{V}$ is shown. Compared to elements in Fig. 1, the leaching patterns were rather different, but consistent. The solubility minima and maxima were found at $\mathrm{pH} 4-6$ and at $\mathrm{pH} 8$ 11 , respectively, for all the elements and materials.

At $\mathrm{pH}$ above 10 the difference in carbonation can be recognised in the leaching trend, as the sharpest alkaline V-shape was found for the non-carbonated materials (except for $\mathrm{V}$ due to concentrations lower than the limit of detection). This shows the important role of the hydrate phases. As the $\mathrm{pH}$ drops below the material $\mathrm{pH}$, all hydrate phases are destabilised and the adsorbed or incorporated metals in these phases are mobilised. When the $\mathrm{pH}$ is increased above the material $\mathrm{pH}$, increased leaching of $\mathrm{Cr}$ and Mo was more pronounced in the carbonation-free samples. It has been shown earlier by Engelsen et al. [2] that the leaching of $\mathrm{SO}_{4}{ }^{2-}$ in the high alkaline $\mathrm{pH}$ range gave the same $\mathrm{V}$-shape as shown here for $\mathrm{Cr}$ and $\mathrm{Mo}$. In addition, the 

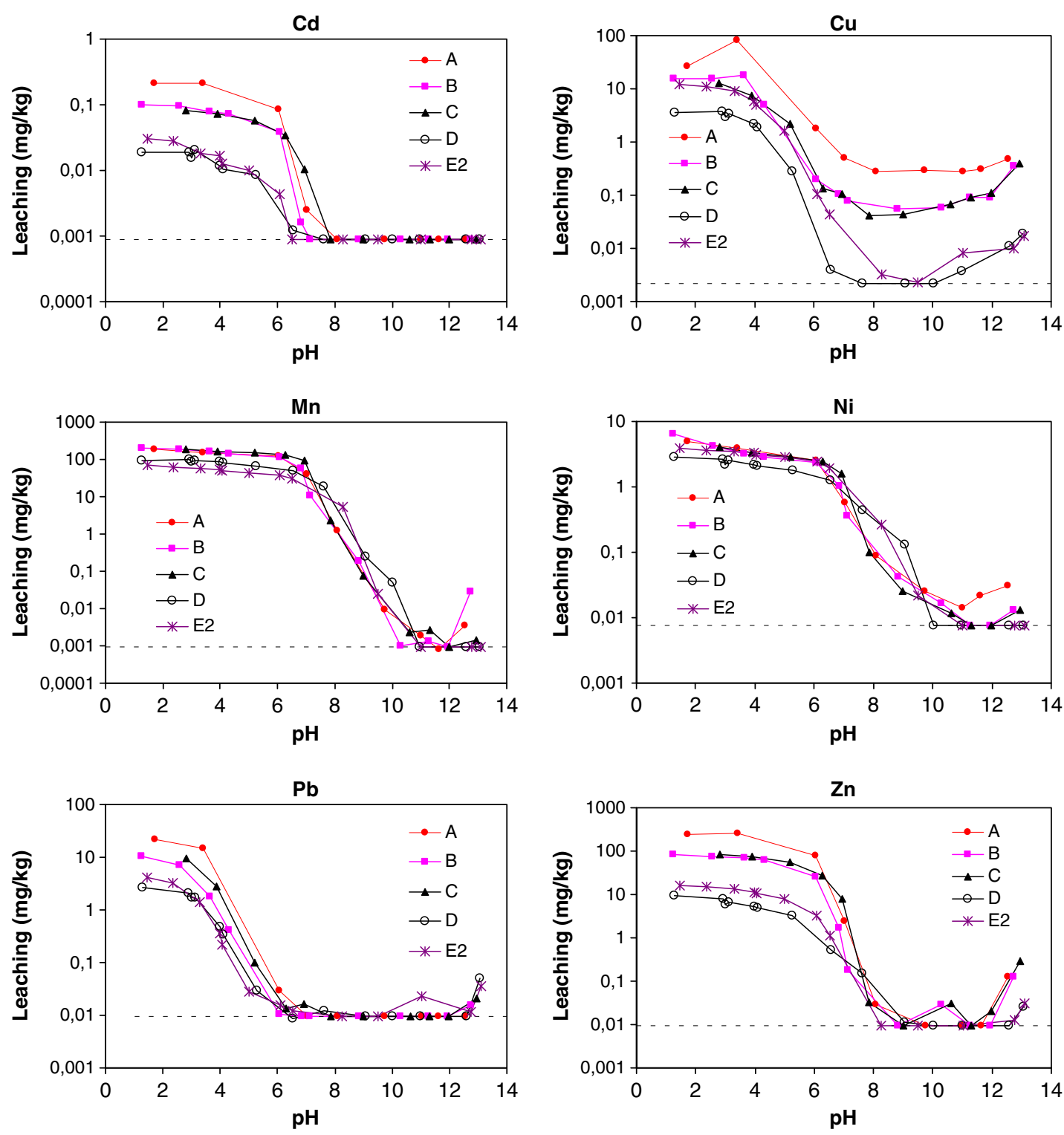

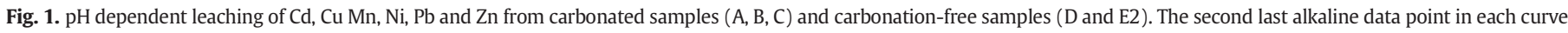

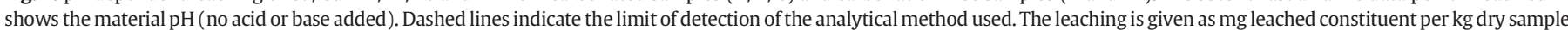

leaching of $\mathrm{Al}$ increased when the $\mathrm{pH}$ was raised above the material $\mathrm{pH}$ due to increased solubility of $\mathrm{SO}_{4}$-AFt (ettringite) [36]. The geochemical speciation modelling also predicted ettringite as one of

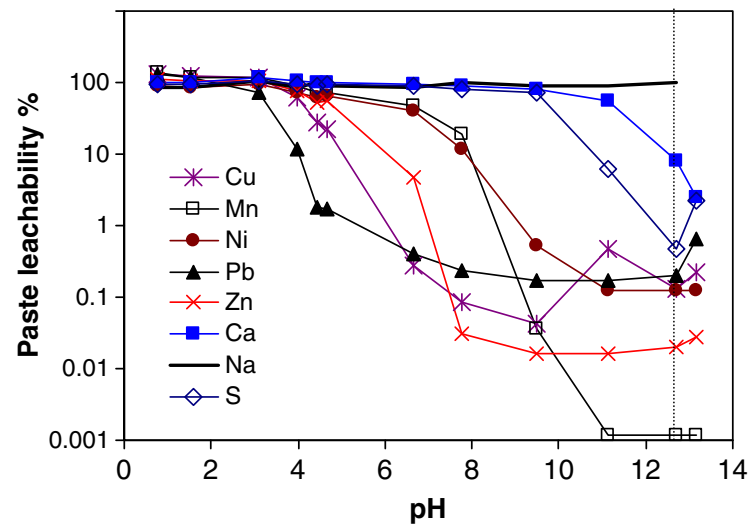

Fig. 2. pH dependent leaching expressed as wt.\% of the total concentrations in the paste for sample E1. Vertical dashed line indicates the material $\mathrm{pH}$. the phases that controlled the solubility of $\mathrm{Al}$ and $\mathrm{S}$ around material $\mathrm{pH}$. This indicates that binding of $\mathrm{Cr}$ and Mo to sulphoaluminates is causing the alkaline $\mathrm{V}$-shape for $\mathrm{Cr}$ and Mo in Fig. 3.

Several authors have pointed out the possibility of substitution of the $\mathrm{SO}_{4}{ }^{2-}$ in the interchannels of ettringite $\left(\mathrm{SO}_{4}-\mathrm{AFt}\right)$ by oxyanions such as $\mathrm{CrO}_{4}{ }^{2-}$ and $\mathrm{MoO}_{4}{ }^{2-}$. An overview is given in Chrysochoou and Dermatas [39]. Poellman and Wenda [40] synthesised AFt solid solution of $\mathrm{CrO}_{4}{ }^{2-}$ and $\mathrm{SO}_{4}{ }^{2-}$. Furthermore, Palou et al. [41] synthesised a mixture of $\mathrm{CrO}_{4}$ and $\mathrm{SO}_{4} \mathrm{AFt}$ and concluded that the substitution was dependent on the chromate content. On the other hand, Chrysochoou and Dermatas [39] reported that substitution of sulphate by oxyanions in the monophases (AFm) was more pronounced at lower oxyanion concentrations (the authors studied the immobilisation in chromite ore processing residues). In Zhang and Reardon [10], $\mathrm{B}(\mathrm{OH})_{4}{ }^{-}, \mathrm{CrO}_{4}{ }^{2-} \mathrm{MoO}_{4}{ }^{2-}$, and $\mathrm{SeO}_{4}{ }^{2-}$ species were shown to substitute for $\mathrm{OH}^{-}$and $\mathrm{SO}_{4}{ }^{2-}$ in synthetic hydrocalumite $\left(\mathrm{Ca}_{4} \mathrm{Al}_{2}(\mathrm{OH})_{12}(\mathrm{OH})_{2} \cdot 6 \mathrm{H}_{2} \mathrm{O}\right)$ and ettringite respectively.

Kindness et al. [11] equilibrated high concentration of $\mathrm{Na}_{2} \mathrm{MoO}_{4} \cdot \mathrm{H}_{2} \mathrm{O}$ with $\mathrm{C}_{3} \mathrm{~A}, \mathrm{C}_{3} \mathrm{~S}, \mathrm{SO}_{4}-\mathrm{AFt}, \mathrm{SO}_{4}$-AFm (separately) and with a Portland cement. Powellite $\left(\mathrm{CaMoO}_{4}\right)$ precipitated in all cases. They also identified high substitution of $\mathrm{SO}_{4}{ }^{2-}$ by $\mathrm{MoO}_{4}{ }^{2-}$ in the AFm synthetic 

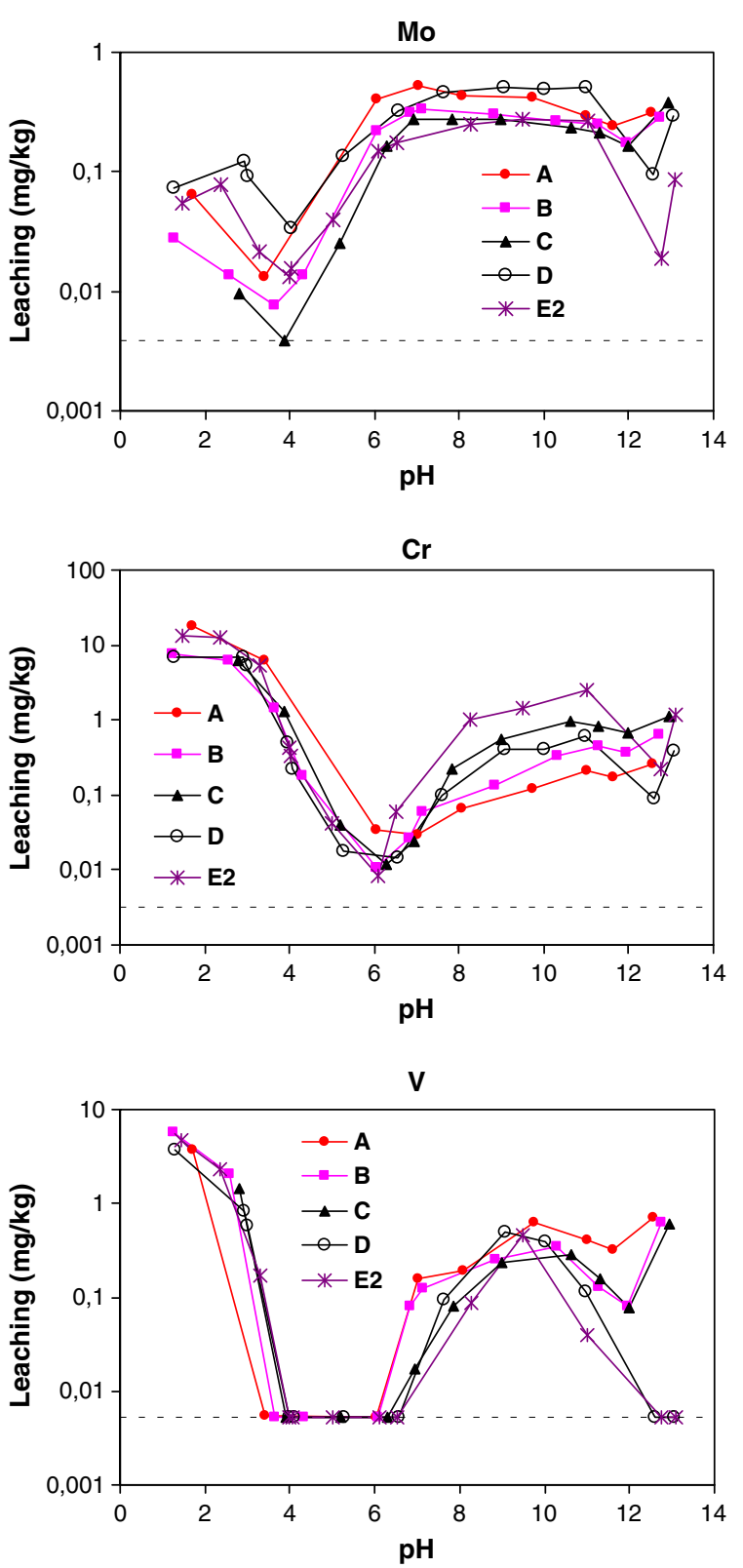

Fig. 3. $\mathrm{pH}$ dependent leaching of $\mathrm{Cr}, \mathrm{V}$ and Mo from samples $\mathrm{A}, \mathrm{B}, \mathrm{C}, \mathrm{D}$ and $\mathrm{E} 2$. The second last alkaline data point in each curve shows the material $\mathrm{pH}$ (no acid or base added). Dashed lines indicate the limit of detection. The leaching is given as $\mathrm{mg}$ leached constituent per kg dry sample.

phase. The binding mechanisms for vanadium $\left(\mathrm{VO}^{2+}\right.$ and $\left.\mathrm{VO}_{4}{ }^{3-}\right)$ in the cement hydrate phases are more unclear as not many studies exist. Other studies $[42,43]$ have shown strong $\mathrm{pH}$ dependence of $\mathrm{V}$ release, and substitution by $\mathrm{SO}_{4}{ }^{2-}$ in ettringite has been indicated.

Based on the existing findings and indications in the literature, $\mathrm{Cr}$ and $\mathrm{Mo}$ (in addition to the metal cations $\mathrm{Cu}$ and $\mathrm{Ni}$ ) were subject to geochemical speciation modelling, assuming their presence as oxyanions (see 3.4 and 3.5.).

\subsection{Identification of hydrate phases at material $\mathrm{pH}$}

The partitioning of the elements between the solid and liquid phases at different $\mathrm{pH}$ values was both measured and predicted. According to recent solubility measurements [18] the stability constant $(\log \mathrm{K})$ for hydrogarnet $\left(\mathrm{C}_{3} \mathrm{AH}_{6}\right)$ was found to be -20.84 , which indicates a significantly lower stability than earlier expected $(-22.46)$ [17]. In the same study [18], the solubility constant for monosulphate $\left(\mathrm{C}_{4} \mathrm{AS}^{\prime} \mathrm{H}_{12}\right)$ was found to be -29.26 . In the present study we used the new constant for hydrogarnet and due to the small difference we used the existing value $(-29.43)$ for monosulphate. The full speciation at material $\mathrm{pH}$ calculated by the model is given in Table 4 for sample E2. Compared to the speciation given earlier [2], the major difference by using the new stability constant was that hydrogarnet did not appear as a major solubility controlling hydrate phase as before. This new finding is in agreement with what is actually found in hydrated Portland cement (CEM I). Moreover, the model predicted the presence of calcium carboaluminates (hemi form) and this suppressed the monosulphates and thus stabilised the ettringite phase. This illustrates that relatively small changes in the stability constants may have a marked effect on the calculated species distribution, making other phase combinations possible. However, the current description provides a phase assemblages which is expected in a Portland cement system. Further improvements in species predictions can be made in parallel to improvements of the underlying thermodynamic data.

From the full speciation predictions in Table 4 (element distribution among mineral phases and aqueous phase), it was possible to quantify the content of hydrates in the cement paste since the dissolved content is small at material $\mathrm{pH}$. The mineral phase contents were calculated using the available amount of the major constituents (leached at $\mathrm{pH}<2$ ) and from the predicted distribution of these constituents in Table 4, the amount of each solid phase was calculated in the cement paste of the sample. Taking into account the measured paste content of $17.9 \%$ in sample E2, and assuming no contribution from the aggregates, $95 \%$ of the solid phases in the paste were predicted by the calculations as shown in Fig. 4. The predictions agreed with the experimentally measured contents of $\mathrm{C}-\mathrm{S}-\mathrm{H}$, portlandite and ettringite (Table 3 ), which were approximately $40 \%$, $20 \%$ and $8 \%$, respectively (accounted for $100 \%$ cement paste).

The leaching experiments were conducted at a L/S of 10 , which means that the conditions were quite different from the paste and pore water system in the concrete. This can be seen when the material $\mathrm{pH}$ determined in the leaching test $(\sim 12.8)$ is compared to the corresponding concrete pore water system where the $\mathrm{pH}$ normally is 13.5. The aqueous concentrations of $\mathrm{Al}, \mathrm{Si}$ and $\mathrm{SO}_{4}{ }^{2-}$ were considerably lower in the former system (in the range 0.36-7.4 $\mu \mathrm{M}$ ) at materials $\mathrm{pH}$, whereas the concentration of $\mathrm{Ca}$ was found to be higher $(18 \mathrm{mM})$, compared to what is normally found in a Portland cement concrete pore water system. This means that a major part of the aqueous $\mathrm{Ca}$ in Table 4 ( $\sim 5 \mathrm{~mol} \%$ of the total leachable $\mathrm{Ca})$ was dissolved from portlandite due to the decrease in $\mathrm{pH}$. Assuming this, the quantity of portlandite was recalculated to be $20 \%$ in the cement paste, in accordance with the XRD results. Speciation predictions carried out for our system at $\mathrm{pH} 13.5$ gave an ettringite content of $11 \%$, which is closer to the content we can expect for the cement system

Table 4

Speciation calculation of the solubility controlling mineral phases for the major elements in sample E2 given as the distribution of the elements in solid and aqueous phases in the leaching suspensions at material $\mathrm{pH}$ (12.8).

\begin{tabular}{lrlllll}
\hline Mineral $^{\mathrm{a}}$ & $\mathrm{Ca}$ & $\mathrm{Si}$ & $\mathrm{Al}$ & $\mathrm{Fe}$ & $\mathrm{SO}_{4}{ }^{2-}$ & $\mathrm{Mg}$ \\
\hline $\mathrm{C}-\mathrm{S}-\mathrm{H}^{\mathrm{b}}$ & 35.8 & 98 & - & - & - & - \\
$\mathrm{Ca}(\mathrm{OH})_{2}$ & 27.7 & - & - & - & - & - \\
$\mathrm{C}_{6} \mathrm{AS}_{3}^{\prime} \mathrm{H}_{32}$ & 9.4 & - & 31.9 & - & 99.1 & - \\
$\mathrm{C}_{4} \mathrm{AC}^{\prime}{ }_{0.5} \mathrm{H}_{11.5}$ & 13.4 & - & 67.9 & - & - & - \\
$\mathrm{C}_{4} \mathrm{FC}_{0.5}{ }_{0.5} \mathrm{H}_{11.5}$ & 4.6 & - & - & 57.8 & - & - \\
$\mathrm{C}_{3} \mathrm{FH}_{6}$ & 2.5 & - & - & 42.2 & - & - \\
$\mathrm{Mg}(\mathrm{OH})_{2}$ & - & - & - & - & - & 100 \\
Hydrous ferric oxide & 1.4 & 1.8 & - & - & - & - \\
Aqueous phase & 5.2 & 0.2 & 0.2 & - & 0.9 & - \\
\hline
\end{tabular}

The results are given in mol\% of the element relative to the maximum leachable concentration.

a $\mathrm{C}=\mathrm{CaO}, \mathrm{S}=\mathrm{SiO}_{2}, \mathrm{~A}=\mathrm{Al}_{2} \mathrm{O}_{3}, \mathrm{~F}=\mathrm{Fe}_{2} \mathrm{O}_{3}, \mathrm{H}=\mathrm{H}_{2} \mathrm{O}, \mathrm{S}^{\prime}=\mathrm{SO}_{3}$ and $\mathrm{C}^{\prime}=\mathrm{CO}_{2}$.

b $\left[\mathrm{Ca}(\mathrm{OH})_{2}\right]_{1.5}\left(\mathrm{SiO}_{2}\right)_{0.9}\left(\mathrm{H}_{2} \mathrm{O}\right)_{0.9}$. 


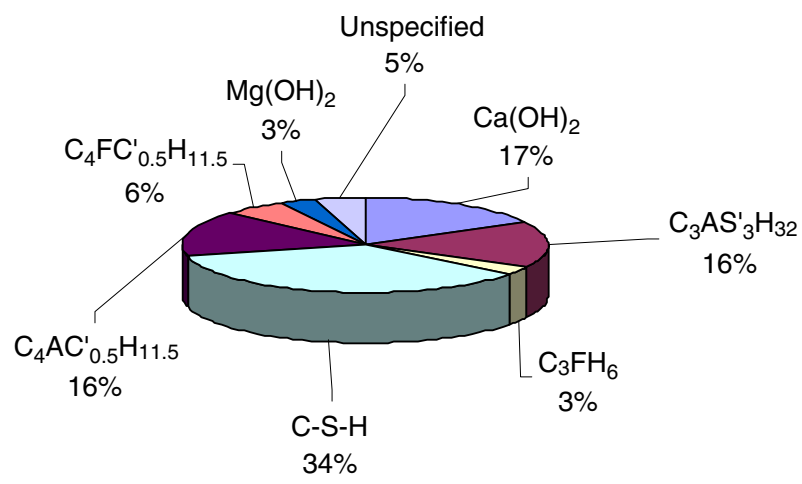

Fig. 4. Cement paste mineralogy in sample E2. The quantities are given in wt.\% of the cement paste. Calculations are based on the element speciation in Table 4 at material $\mathrm{pH}$. Unspecified content refers largely to the dissolved $\mathrm{Ca}(\mathrm{OH})_{2}$. Cement Chemistry notification: $\mathrm{C}=\mathrm{CaO}, \mathrm{S}=\mathrm{SiO}_{2}, \mathrm{~A}=\mathrm{Al}_{2} \mathrm{O}_{3}, \mathrm{~F}=\mathrm{Fe}_{2} \mathrm{O}_{3}, \mathrm{H}=\mathrm{H}_{2} \mathrm{O}, \mathrm{S}^{\prime}=\mathrm{SO}_{3}$ and $\mathrm{C}^{\prime}=\mathrm{CO}_{2}$.

under consideration. It is also in the same range as the XRD results (8\%).

\subsection{Model predictions of $\mathrm{Cu}$ and $\mathrm{Ni}$ release}

In Fig. 5 the equilibrium concentrations of $\mathrm{Cu}$ and Ni predicted by the geochemical model are shown for the samples A, D and E2. These samples covered both the most carbonated sample (A) and the carbonation-free samples taken from field site (D) and cast in laboratory (E2). The other samples showed similar behaviour. The characteristic shapes of the experimental leaching curves were simulated well by the model over almost the entire $\mathrm{pH}$ range, considering the fact that the equilibrium concentrations changed several orders of magnitude. For $\mathrm{Cu}$ and $\mathrm{Ni}$ it can be seen that the model suggests $\mathrm{CuO}$ (tenorite) and $\mathrm{Ni}(\mathrm{OH})_{2}$ as the dominant mineral controlling phases at $\mathrm{pH}>9.5$. If tenorite is disregarded in the mineral assembly for sample $A$, the model suggests precipitation of $\mathrm{Cu}(\mathrm{OH})_{2}$ which improved the match between predicted and measured values in the $\mathrm{pH}$ range $9-11.5$. The predicted concentrations of "free" metals were overestimated in the highest $\mathrm{pH}$ region, as the (hydr)oxides should start to dissolve according to the model.

It seems clear that the "retention" in the hydrate phases caused the lower concentrations measured for D and E2 compared to A. For C-S-
$\mathrm{H}$, this is expected based on earlier studies regarding the ability to bind metal cations (e.g. $\mathrm{Cu}$ and $\mathrm{Ni}$ ) $[13,14,16]$. Another binding mechanism for $\mathrm{Ni}$ is identified to be the formation of $\mathrm{Ni}-\mathrm{Al}$ layered double hydroxide ( $\mathrm{LDH}$ ) phases [44-46]. The phases are commonly expressed as $\left[\mathrm{M}^{\mathrm{II}}{ }_{1-\mathrm{x}} \mathrm{M}^{\mathrm{III}}{ }_{\mathrm{x}}(\mathrm{OH})_{2}\right]^{\mathrm{x}+}\left(\mathrm{A}^{\mathrm{n}-}\right)_{\mathrm{x} / \mathrm{n}} \cdot y \mathrm{H}_{2} \mathrm{O}$ and it has been suggested that the $\mathrm{M}^{\mathrm{II}}$ position can partly be filled by $\mathrm{Ni}$, $\mathrm{M}^{\mathrm{III}}$ with $\mathrm{Al}$ whereas $\mathrm{A}^{\mathrm{n}-}$ may be $\mathrm{CO}_{3}{ }^{2-}, \mathrm{NO}_{3}{ }^{-}, \mathrm{Cl}^{-}$and $\mathrm{SO}_{4}{ }^{2-}$. The cited studies also indicated that $\mathrm{Ni}(\mathrm{OH})_{2}$ coexisted to a minor extent with the $\mathrm{Ni}-\mathrm{Al}$ LDH phases. At a low Ni concentration in the cement paste $(50 \mathrm{mg} /$ $\mathrm{kg}$ ), precipitation of these hydroxides was found to be insignificant [45]. The speciation model used in the present study was unable to identify these complex mechanisms, as the reaction mechanisms are not fully understood, and improvements can thus be made only if relevant solubility data become available.

For sample A the organic interaction (see Section 2.4) was included in the model as can be seen in the binding to the humic substances in the particular organic matter (POM) and the humic substances that are part of the dissolved organic carbon (DOC). Especially for $\mathrm{Cu}$ this influence was significant. The higher $\mathrm{Cu}$ concentrations obtained in the leachates for A compared to D and E2 in the pH region 6-11 could not be simulated without taking these interactions into account. This is supported by the measured humic fractions in samples A-C derived from the selective extractions. Note that the relatively small fraction of humic substances enhances the copper leaching significantly.

Below pH around 9.5, the model predicted that cation sorption to reactive oxide surfaces, modelled as sorption to hydrous ferric oxide (HFO), was starting to be the predominating process for both elements in all samples. The solubility minima for $\mathrm{Cu}$ (i.e. sorption maxima) were around neutral $\mathrm{pH}$. In an earlier study of the sorption of $\mathrm{Cu}^{2+}$ to synthetic hydrous oxides of aluminium and iron, maximum sorption was achieved when the $\mathrm{pH}$ reached 7-8 [47]. In sample A, binding to POM was also significant. The simulated and measured concentrations were in good agreement in this $\mathrm{pH}$ region. As the $\mathrm{pH}$ was decreasing towards the most acidic region, the predicted concentrations (and the measured) were approaching the available concentrations (maximum leachability).

\subsection{Model predictions of $\mathrm{Cr}$ and Mo release}

The modelling was carried out for $\mathrm{Cr}$ and Mo anticipating their existence as oxyanions $\left(\mathrm{MoO}_{4}{ }^{2-}\right.$ and $\left.\mathrm{CrO}_{4}{ }^{2-}\right)$ in ettringite solid solutions (Ettr SS) at alkaline $\mathrm{pH}$. The system was described as ideal
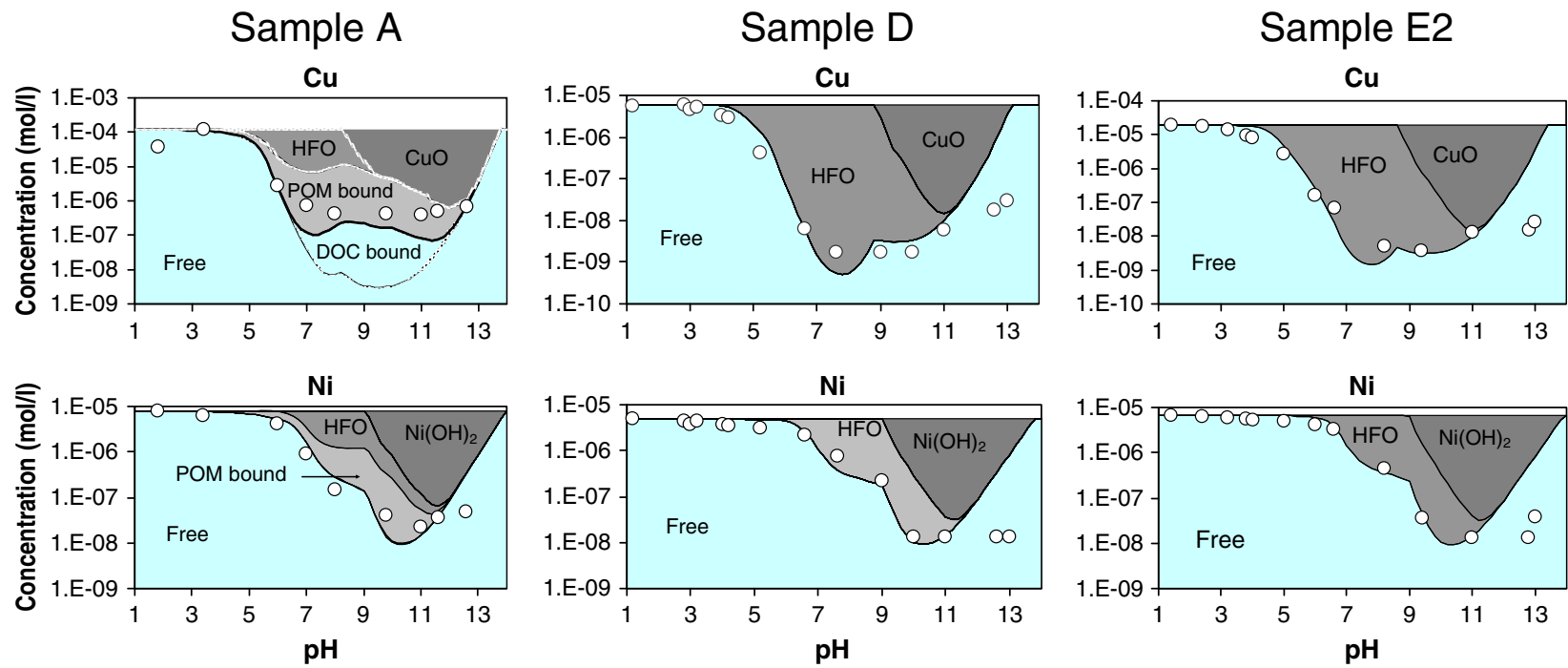

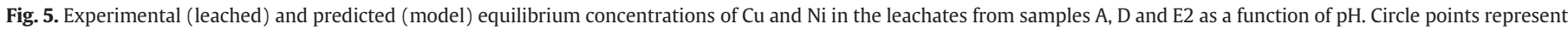

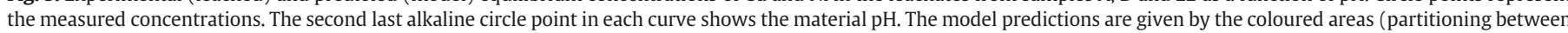
the solid phase and aqueous phase). Abbreviations: HFO = hydrous ferric oxide, $\mathrm{DOC}=$ dissolved organic carbon and POM $=$ particular organic matter. 

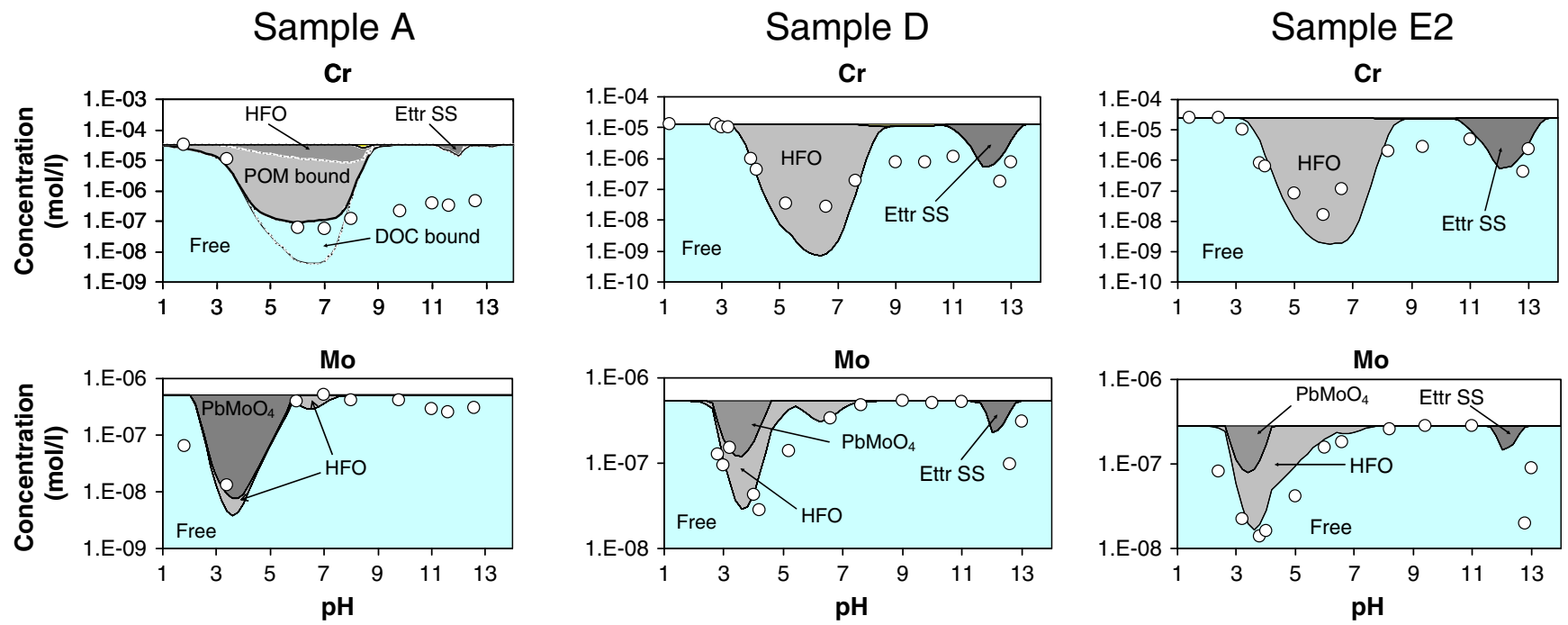

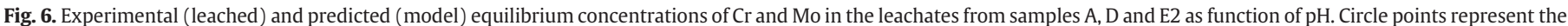

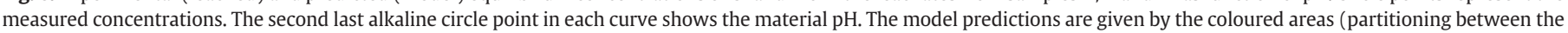

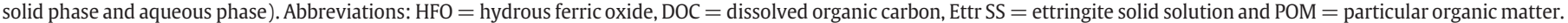

solid solutions [48] as the activity of each member phase is equal to its mole fraction. In addition, the solubility products of the end members were chosen to be equal to their respective pure phases. The model calculations showed reasonable agreement between predicted and experimental concentrations of $\mathrm{Cr}$ in the $\mathrm{pH}$ region 11-13 for the carbonation-free samples (D and E2), see Fig. 6. The characteristic V-shapes in the alkaline region were also well simulated by the model. For the same samples and at high alkaline $\mathrm{pH}$, a poorer correlation was achieved for Mo, although a small solubility minimum could be predicted at material $\mathrm{pH}$. The main controlling phases suggested by the model at this $\mathrm{pH}$ were $\mathrm{MoO}_{4}{ }^{2-}$ and $\mathrm{CrO}_{4}{ }^{2-}$ bound as ettringite solid solutions. In the case of Mo, the concentrations in the solid phase (as ettringite) were underestimated. Comparing the samples E1, E2 and E3, the predicted concentration of Mo decreased significantly as the paste content decreased, whereas the measured concentrations were almost the same. Whether this was caused by interactions with other phases than ettringite (e.g. AFm phases) or due to incorrect solubility constant for the $\mathrm{MoO}_{4}{ }^{2-}$ ettringite solid solution, could not be decided with the current data set and reaction descriptions. In separate model calculations without the oxyanion solid solution formation, we were not able to find mineral phases with acceptable saturation indices at these high $\mathrm{pH}$ values. In our recent study, fractionation analyses were carried out for assessing the charge of $\mathrm{Cr}$ and $\mathrm{Mo}$ in the leachates $\mathrm{pH} \mathrm{8.5-12.5)}$ of sample E1 by applying a strong anion exchange sorbent [49]. The results showed that the anionic form of $\mathrm{Cr}$ and Mo predominates in the leachates, most likely as $\mathrm{MoO}_{4}{ }^{2-}$ and $\mathrm{CrO}_{4}{ }^{2-}$. For sample $\mathrm{A}$ the ettringite solid solution effect was not predicted which agreed with the fact that this phase was absent to a large extent.

The acidic solubility minima in Fig. 6 (Mo and $\mathrm{Cr}$ ) were predicted by the model, and were in fair agreement with the measured concentrations at $\mathrm{pH} 4$ and 6 . The speciation calculations predicted that $\mathrm{Cr}$ and Mo were sorbed to hydrous ferric oxide (HFO) at these solubility minima. In addition, the sorption process for Mo (as $\mathrm{MoO}_{4}{ }^{2-}$ ) was competing with precipitation of $\mathrm{PbMoO}_{4}$, as indicated in Fig. 6. The extent of $\mathrm{PbMoO}_{4}$ precipitation depended on the available amount of HFO and was therefore affected by the cement paste content in the leaching system (fixed $\mathrm{L} / \mathrm{S}$ ). In separate model trials (not shown) it was found that by increasing the amount of HFO, the sorption process became predominant. However, this resulted in poorer correlations between predicted and measured concentrations. The sorption of $\mathrm{MoO}_{4}{ }^{2-}$ was mostly encountered at
pH 4-5, in agreement with Bibak and Borggaard [50] who studied the sorption of $\mathrm{MoO}_{4}{ }^{2-}$ to synthetic goethite and ferrihydrite. Sorption maxima of $\mathrm{MoO}_{4}{ }^{2-}$ at $\mathrm{pH}$ 4-5 have also been reported in later studies [51,52].

In the case of $\mathrm{Cr}$, the HFO surface complexation model used in Orchestra includes sorption of $\mathrm{Cr}(\mathrm{III})$ and $\mathrm{Cr}(\mathrm{VI})$ species. In a recent study it was concluded that ettringite and $\mathrm{CaCrO}_{4}(\mathrm{~s})$ together with surface complexation to ferrihydrite, controlled the $\mathrm{Cr}$ leachability in the entire $\mathrm{pH}$ range for cement stabilized waste (oily sludge and ash) [53]. In Fig. 6 the leachability for Sample A is controlled by sorption to HFO and complexation to humic substances in the solid and liquid phases. The humic substance interactions (POM and DOC bound) in the model were significant for $\mathrm{Cr}^{3+}$ species only.

In samples D and E2 the binding to HFO was predominant. In the surface complexation model, $\mathrm{Cr}(\mathrm{III})$ and $\mathrm{Cr}(\mathrm{VI})$ species are taken into account and both species are present in the cement paste. In European Portland cements, the solid concentration of $\operatorname{Cr}(\mathrm{VI})$ in hydrated cements is usually much lower than $\mathrm{Cr}$ (III) due to chromate reduction by iron sulphate addition during clinker grinding. $\mathrm{The} \mathrm{Cr}($ total $) / \mathrm{Cr}(\mathrm{VI})$ ratio is around 5.5 for sample E2 in Fig. 6, assuming that the leachable contents of $\mathrm{Cr}$ (total) and $\mathrm{Cr}(\mathrm{VI})$ are found at the acidic and alkaline solubility maxima, respectively. This indicates that both species should be included in the geochemical model. Furthermore, separate simulations showed that the sorption was underestimated when only $\mathrm{Cr}(\mathrm{VI})$ (as oxyanions) sorption reactions were considered and overestimated when only $\mathrm{Cr}$ (III) reactions were included in the model. In addition, when HFO reactions were suppressed (low value used) in the $\mathrm{Cr}$ simulation for $\mathrm{E} 2$, the precipitation of $\mathrm{Cr}(\mathrm{OH})_{3}$ was found to be significant, but this was in poor agreement with the experimental values.

\section{Conclusion}

It has been shown that a significant amount of information can be drawn from the $\mathrm{pH}$ dependent leaching characterisation of crushed concrete for the metals investigated. Comparisons of samples taken from the recycling facility (aged) with carbonation-free field and laboratory samples show that the released amounts of the metals are considerably lower at high alkaline $\mathrm{pH}$, due to the interactions with the intact cement hydrate phases of the carbonation-free samples. These interactions were particularly seen for the oxyanion forming elements $\mathrm{Cr}$, Mo and V. 
In general, the geochemical speciation model used was able to predict the measured metal concentrations over almost the entire $\mathrm{pH}$ range. The latest available equilibrium constants for the hydrogarnet phase were used. This improved the chemical description of the leaching system at material $\mathrm{pH}$. The model predicted that hemi carboaluminate was stable, thus suppressing the formation of hydrogarnet. The calculated phase contents based on the speciation predictions for the laboratory sample (E2) agreed with the experimental data from the XRD analyses of portlandite, calcium silicate hydrate and ettringite.

For the metal cations studied, the model showed that the formation of metal hydroxides in the alkaline $\mathrm{pH}$ region is not sufficient to describe the leaching process for carbonation-free samples, and that interactions with the cement hydrate phases are far more important. For the oxyanion forming elements, strong indications for binding to sulfoaluminate phases were obtained from the experimental leaching characterisation. The geochemical speciation modelling predicted that the release mechanisms for $\mathrm{Cr}$ and Mo would be binding to ettringite as solid solution. In the lower $\mathrm{pH}$ region (5-10), sorption to hydrous ferric oxide was predicted to be significant for the metal cations and oxyanions, giving rise to sorption maxima at distinct $\mathrm{pH}$ values. The model will be improved when equilibrium constants in the high alkaline $\mathrm{pH}$ region become available. However, even at the present stage the overall description is giving a fair insight to the predominating leaching mechanisms. Furthermore, the present study helps in identifying the gaps for which future efforts can be made. The current information may form the basis for identification of leaching processes in multicomponent cement systems, e.g. Portland cement, fly ash, bottom ash and silica fume.

\section{Acknowledgement}

This study has been supported by the Norwegian Public Roads Administration, Norcem AS, Elkem AS and BA Gjenvinning AS.

\section{References}

[1] J.J. Dijkstra, J.C.L. Meeussen, R.N.J. Comans, Leaching of heavy metals from contaminated soils: an experimental and modeling study, Environmental Science \& Technology 38 (16) (2004) 4390-4395.

[2] C.J. Engelsen, H.A. van der Sloot, G. Wibetoe, G. Petkovic, E. Stoltenberg-Hansson, W. Lund, Release of major elements from recycled concrete aggregates and geochemical modelling, Cement and Concrete Research 39 (5) (2009) 446-459.

[3] H.A. van der Sloot, Developments in testing for environmental impact assessment, Waste Management 22 (7) (2002) 693-694.

[4] H.A. van der Sloot, Comparison of the characteristic leaching behavior of cements using standard (EN 196-1) cement mortar and an assessment of their long-term environmental behavior in construction products during service life and recycling, Cement and Concrete Research 30 (7) (2000) 1079-1096.

[5] O. Peyronnard O, M. Benzaazoua, D. Blanc a, P. Moszkowicz, Study of mineralogy and leaching behavior of stabilized/solidified sludge using differential acid neutralization analysis Part I: Experimental study, Cement and Concrete research 39 (2009) 600-609.

[6] H.A. van der Sloot, Characterization of the leaching behaviour of concrete mortars and of cement-stabilized wastes with different waste loading for long term environmental assessment, Waste Management 22 (2002) 181-186.

[7] J.C.L. Meeussen, ORCHESTRA: an object-oriented framework for implementing chemical equilibrium models, Environmental Science \& Technology 37 (6) (2003) 1175-1182.

[8] H. A. van der Sloot, P.F.A.B. Seignettte, J.C.L. Meeussen, O. Hjelmar and D.S. Kosson, A database, speciation modelling and decision support tool for soil, sludge, sediments, wastes and construction products: LeachXS ${ }^{\mathrm{TM}}$ - Orchestra. In: Venice Symposium, Venice 2008.

[9] G. Cornelis, C.A. Johnson, T.V. Gerven, C. Vandecasteele, Leaching mechanisms of oxyanionic metalloid and metal species in alkaline solid wastes: a review, Applied Geochemistry 23 (2008) 955-975.

[10] M. Zhang, E.J. Reardon, Removal of B, Cr, Mo, and Se from wastewater by incorporation into hydrocalumite and ettringite, Environmental Science \& Technology 37 (13) (2003) 2947-2952.

[11] A. Kindness, E.E. Lachowski, A.K. Minocha, F.P. Glasser, Immobilization and fixation of molybdenum(VI) by Portland-cement, Waste Management 14 (2) (1994) 97-102.

[12] P. Kumarathasan, G.J. McCarthy, D.J. Hassett, D.F. Pflughoeft-Hassett, Oxyanion substituted ettringites: synthesis and characterisation and their potential role in immobilisation of As, B, Cr, Se and V, Mater. Materials Research Society symposium proceedings 178 (1990) 83-104

[13] S. Komarneni, E. Breval, D.M. Roy, R. Roy, Reactions of some calcium silicates with metal-cations, Cement and Concrete Research 18 (2) (1988) 204-220.

[14] O.P. Shrivastava, F.P. Glasser, Ion-exchange properties of 11- $\AA$ tobermorite reactivity, Solids 2 (1986) 261-268.

[15] F. Ziegler, R. Gierea, C.A. Johnson, Sorption mechanisms of zinc to calcium silicate hydrate: sorption and microscopic investigations, Environmental Science and Technology 35 (2001) 4556-4561.

[16] I. Moulin, W.E.E. Stone, J. Sanz, J.-Y. Bottero, F. Mosnier, C. Haehnel, Lead and zinc retention during hydration of tri-calcium silicate: a study by sorption isotherms and Si-29 nuclear magnetic resonance spectroscopy, Langmuir 15 (1999) 2829-2835.

[17] B. Lothenbach, F. Winnefeld, Thermodynamic modelling of the hydration of Portland cement, Cement and Concrete Research 36 (2) (2006) 209-226.

[18] T. Matschei, B. Lothenbach, F.P. Glasser, Thermodynamic properties of Portland cement hydrates in the system $\mathrm{CaO}-\mathrm{Al}_{2} \mathrm{O}_{3}-\mathrm{SiO}_{2}-\mathrm{CaSO}_{4}-\mathrm{CaCO}_{3}-\mathrm{H}_{2} \mathrm{O}$, Cement and Concrete Research 37 (2007) 1379-1410.

19] H.A. van der Sloot, J.C.L. Meeussen, A. van Zomeren, D.S. Kosson, Developments in the characterisation of waste materials for environmental impact assessment purposes, Journal of Geochemical Exploration 88 (1-3) (2006) 72-76.

[20] J.J. Dijkstra, H.A. van der Sloot, R.N.J. Comans, The leaching of major and trace elements from MSWI bottom ash as a function of $\mathrm{pH}$ and time, Applied Geochemistry 21 (2) (2006) 335-351.

[21] G. Petkovic, C.J. Engelsen, A.O. Haoya, G. Breedveld, Environmental impact from the use of recycled materials in road construction: method for decision-making in Norway, Resources Conservation and Recycling 42 (3) (2004) 249-264.

[22] J. Karlsen, G. Petkovic, O. Lahus, A Norwegian certification scheme for Recycled Concrete Aggregates (RCA), in: T.D. Pettersen (Ed.), Sustainable Building 2002 3rd International Conference on Sustainable Building, 2002, Oslo, Norway.

[23] C.J. Engelsen, H.A. van der Sloot, G. Petkovic, E. Stoltenberg-Hansson, G. Wibetoe, W Lund, Constituent release predictions for recycled aggregates at field site in Norway, in: M. Ilic, J.J.J.M. Goumans, S. Miletic, J.J.M. Heynen, J. Senden (Eds.), WASCON 2006 6th International Conference on the Environmental and Technical Implications of Construction with Alternative Materials, 2006, pp. 293-305, Belgrade.

[24] NT Build 437: Concrete, hardened and mortar; calcium oxide and soluble silica contents, Nordtest method, (1995).

[25] CEN/TS 14429: Characterization of waste - Leaching behaviour tests - Influence of $\mathrm{pH}$ on leaching with initial acid/base addition, (2005).

[26] A. van Zomeren, R.N.J. Comans, Measurement of humic and fulvic acid concentrations and dissolution properties by a rapid batch procedure, Environmental Science and Technology 41 (19) (2007) 6755-6761.

[27] R.S. SWIFT, Organic matter characterization, Methods of soil analysis, Part 3, Chemical methods, Sparks, D.L. (Ed.), Madison, Wis: Soil Science Society of America, Book Series: 5, 1011-1069.

[28] J.E. Kostka, G.W. Luther III, Partitioning and speciation of solid-phase iron in saltmarsh sediments, Geochimica Et Cosmochimica Acta 58 (7) (1994) 1701-1710.

[29] L.C. Blakemore, P.L. Searle, B.K. Daly, Methods for chemical analysis of soils, Sci. Rep., 80, NZ soil Bureau; Lower Hutt, New Zealand, 1987.

[30] J.D. Allison, D.S. Brown, K.J. Novo-Gradac, MINTEQA2/PRODEFA2, Geochemical assessment model for environmental systems: version 3.11 databases and version 3.0 user's manual, Environmental Research Laboratory (1991) U.S. EPA: Athens, GA, viii, 106 p.

[31] D.G. Kinniburgh, W.H. van Riemsdijk, L.K. Koopal, M. Borkovec, M.F. Benedetti, M.J. Avena, Ion binding to natural organic matter: competition, heterogeneity, stoichiometry and thermodynamic consistency, Colloids and Surfaces A: Physicochemical and Engineering Aspects 151 (1-2) (1999) 147-166.

[32] C.J. Milne, D.G. Kinniburgh, W.H. Van Riemsdijk, E. Tipping, Generic NICA-Donnan model parameters for metal-ion binding by humic substances, Environmental Science \& Technology 37 (5) (2003) 958-971.

[33] A. van Zomeren, A. Costa, J.P. Pinheiro, R.N.J. Comans, Proton binding properties of humic substances originating from natural and contaminated materials, Environ. Sci. Technol. 43 (5) (2009) 1393-1399.

[34] J.J. Dijkstra, A. van Zomeren, J.C.L. Meeussen, R.N.J. Comans, Effect of accelerated aging of MSWI bottom ash on the leaching mechanisms of copper and molybdenum, Environmental Science and Technology 40 (14) (2006) 4481-4487.

[35] D.A. Dzombak, F.M.M. Morel, Surface Complexation Modeling; Hydrous Ferric Oxide, John Wiley \& Sons, New York, 1990.

[36] C.J. Engelsen, P. Fidjestøl, H.A. van der Sloot, H. Justnes, M. Mulugeta, In Proceedings: International Conference Sustainable Concrete Construction, India Chapter of American Concrete Institute, Rantnagiri, India, 2008, pp. 109-116.

[37] F. Ziegler, C.A. Johnson, The solubility of calcium zineate $\left(\mathrm{CaZn}_{2}(\mathrm{OH})_{6} \cdot 2 \mathrm{H}_{2} \mathrm{O}\right)$ Cement and Concrete Research 31 (9) (2001) 1327-1332.

[38] D.F. Shriver, P.W. Atkins Inorganic Chemistry 3rd ed.; Oxford University Press, (1999).

[39] M. Chrysochoou, D. Dermatas, Evaluation of ettringite and hydrocalumite formation for heavy metal immobilization: literature review and experimental study, Journal of Hazardous Materials 136 (1) (2006) 20-33.

[40] H. Poellman, R. Wenda, Solid solutions of ettringites Part II, Cement and Concrete Research 23 (1993) 422-430.

[41] M. Palou, J. Majling, M. Drabik, A. Ayadi, Ettringite and its chromate analogue structure and thermal stability, Solid State Chemistry V 90-91 (2003) 395-400.

[42] R.B. Heimann, D. Conrad, L.Z. Florence, M. Neuwirth, D.G. Ivey, R.J. Mikula, W.W Lam, Leaching of simulated heavy-metal waste stabilized solidified in different cement matrices, Journal of Hazardous Materials 31 (1) (1992) 39-57.

[43] H.A. van der Sloot, D. Hoede, R.P.J.J. Rietra, R. Stenger, T. Lang, M. Schneider, G. Spanka, E. Stoltenberg-Hansson, A. Lerat, Environmental criteria for cement based 
products - ECRICEM - Phase 1: Ordinary Portland cements, Energy Research Centre of the Netherlands (ECN) (2001) ECN-C-01-069.

[44] A.M. Sceidegger, E. Wieland, A.C. Scheinost, R. Dahn, P. Spieler, Spectroscopic evidence for the formation of layered $\mathrm{Ni}-\mathrm{Al}$ double hydroxides in cement, Environmental Science and Technology 34 (21) (2000) 4545-4548.

[45] M. Vespa, R. Dähn, D. Grolimund, E. Wieland, A.M. Scheidegger, Spectroscopic investigation of Ni speciation in hardened cement paste, Environmental Science and Technology 40 (7) (2006) 2275-2282.

[46] M. Vespa, R. Dähn, D. Grolimund, E. Wieland, A.M. Scheidegger, The influence of hydration time on the Ni uptake by cement, Czechoslovak Journal of Physics 56 (2006) 599-607.

[47] K.G. Karthikeyan, H.A. Elliott, Surface complexation modeling of copper sorption by hydrous oxides of iron and aluminum, Journal of Colloid and Interface Science 220 (1) (1999) 88-95.

[48] D.L. Parkhurst, C.A.J. Appelo, User's guide to PHREEQC (version 2) - a compute program for speciation, reaction-path, 1D-transport, and inverse geochemical calculations, US Geological Survey Water Resources Investigation report (1999) Rep. 99-4259, xiv, 312p.

[49] M. Mulugeta, C.J. Engelsen, G. Wibetoe, W. Lund, Charge-based fractionation of oxyanion-forming metals and metalloids leached from recycled concrete aggregates of different degrees of carbonation: a comparison of laboratory and field leaching tests, Waste Management (2010), in press, http://dx.doi.org/10.1016/j.wasman.2010.05.003.

[50] A. Bibak, O.K. Borggaard, Molybdenum adsorption by aluminum and iron-oxides and humic-acid, Soil Science 158 (5) (1994) 323-328.

[51] J.P. Gustafsson, Modelling molybdate and tungstate adsorption to ferrihydrite, Chemical Geology 200 (1-2) (2003) 105-115.

[52] N. Xu, C. Christodoulatos, W. Braida, Adsorption of molybdate and tetrathiomolybdate onto pyrite and goethite: effect of $\mathrm{pH}$ and competitive anions, Chemosphere 62 (10) (2006) 1726-1735.

[53] A.K. Karamalidis, E.A. Vouldrias, Release of $\mathrm{Zn}, \mathrm{Ni}, \mathrm{Cu}, \mathrm{SO}_{4}{ }^{2-}$ and $\mathrm{CrO}_{4}{ }^{2-}$ as a function of $\mathrm{pH}$ from cement-based stabilized/solidified refinery oily sludge and ash from incineration of oily sludge, Journal of Hazardous Materials 141 (3) (2007) 591-606. 